\title{
Upper Ordovician glacial deposits in Saudi Arabia
}

\begin{abstract}
One of the major results of the geologic mapping program of the Saudi Arabian Directorate General of Mineral Resources is the demonstration of ubiquitous Upper Ordovician glacial and periglacial, continental to subaquatic deposits in lower Paleozoic outcrops of Saudi Arabia. A precise link has been established between these deposits and the icecap that existed on the Gondwana paleocontinent in Late Ordovician time. Two major phases of ice advance and retreat, each marked by a pronounced erosional unconformity, are recorded in central and northwestern Arabia. Graptolite zonation indicates that marine clay sedimentation began after the icecap melted: by middle Llandoverian time in central Arabia and by early Llandoverian time in northwestern Arabia.

Updated paleofacies maps have been integrated with lithologic comparisons in order to establish correlations between the deposits of central Arabia and those of other regions of the Arabian Peninsula, northern and western Africa, Turkey, Iran, and Syria. As a result of this work, the early Paleozoic geodynamic evolution of Arabia clearly belongs to the broader paleogeographic context of the Gondwana paleocontinent and its margins.
\end{abstract}

\section{Introduction}

Early Paleozoic rocks in Saudi Arabia crop out in three areas as a discontinuous fringe around the Proterozoic Arabian Shield (fig. 1): (1) in the northwestern (Tabuk) area extending west from the Great Nafud (An Nafud) to Jordan, (2) in the central area including the $\mathrm{Ha}$ il and Qasim regions in central Arabia, and (3) in the southern area extending from Jabal Wajid to North Yemen. These outcrops are bounded to the north by the erosional surface beneath the Upper Cretaceous Wasia Formation and to the northeast and east by the erosional surface beneath the Upper Permian Khuff Formation. Upper Permian deposits directly overlie the eastern part of the Shield. In southern Arabia, the Khuff Formation is missing and the Paleozoic is overlain directly by Jurassic deposits.

Paleozoic rocks of central Saudi Arabia have been studied in detail by the French Bureau de Recherches Géologiques et Minières (BRGM) as part of the Saudi Arabian Directorate General of Mineral Resources`(DGMR's) systematic geologic mapping program of the
Kingdom. New data have been published by DGMR on the early Paleozoic lithostratigraphy resulting from this work as 1:250,000scale geologic maps and explanatory notes (Vaslet and others, 1985: Manivit and others, 1986; Williams and others, 1986; Ekren and others, 1987; Vaslet and others, 1987), and these data have been summarized in a DGMR Professional Paper (Vaslet, 1989).

Before 1985, the stratigraphy of lower Paleozoic rocks of Saudi Arabia was based mostly on the international stratigraphic lexicon (Powers, 1968), which formalized the earlier work of Thralls and Hasson (1956). Steineke and others (1958), and Powers and others (1966).

In the scheme proposed by Powers (1968), the early Paleozoic succession of central Saudi Arabia was subdivided into two formations (fig. 2): (1) the Cambrian(?) to Early Ordovician (Arenigian) Saq Sandstone, unconformably overlying Proterozoic Shield rocks and composed of conglomeratic and coarse- to fine-grained sandstone and siltstone; and (2) the Tabuk Formation, conformable on the Saq Sandstone, consisting of shale and sandstone and subdivided into seven informal units considered to range in age from Early Ordovician (Arenigian) to Early Devonian (Gedinnian). Helal (1964, 1965) used a different terminology and restricted the Tabuk Formation to Ordovician deposits. He defined a new formation for the Tabuk region Silurian rocks, that is, the Sharawra formation. Helal (1964) also considered the base of the Tabuk Formation to be Llanvirnian Bahafzallah and others (1981) and Al-Laboun (1982, 1986) proposed the amputation of the upper, the Devonian, part of the Tabuk Formation, that is, the Tawil Member of Powers (1968).

McClure (1978) and Young (1981) were the first to describe glacial deposits of early Paleozoic age from central Saudi Arabia (Jal as Saqiyah). These deposits were (partly) mapped by Bramkamp and others (1963) as "brown to tan sandstone [that] transgresses the lower and middle parts of the [Tabuk] formation," although they were not interpreted as such at that time.

In 1978, McClure tentatively referred to the Late Ordovician glaciation previously described in the Sahara (Beuf and others, 1971), although he concluded that insufficient data were available. The existence of Late Ordovician glacial environments was corroborated by a sedimentologic study by Clark-Lowes (1980) in the Qasim region. This latter author proposed the nomenclature of the "Sarah member" for glacial deposits that formed part of the "Tabuk Formation" defined by Powers (1968).

Detailed study of the stratigraphic succession that includes these glacial deposits led Vaslet (1987a, b, c: 1989) to recognize two major glacial erosional surfaces that underlie the glacial to periglacial deposits within the "Tabuk Formation" of Powers (1968). Lithostratigraphic evidence clearly demonstrates the need for revision of the Tabuk Formation. which must be considered an obsolete unit in view of the internationally accepted rules of stratigraphic nomenclature.

New lithostratigraphic units replacing the former "Tabuk Formation" were defined and featured on the DGMR Geoscience Maps published for the Ha'il and Qasim regions, and a synthesis of the currently available lithostratigraphic, sedimentologic, and biostratigraphic data has been summarized in a DGMR Professional Paper (Vaslet, 1989). 


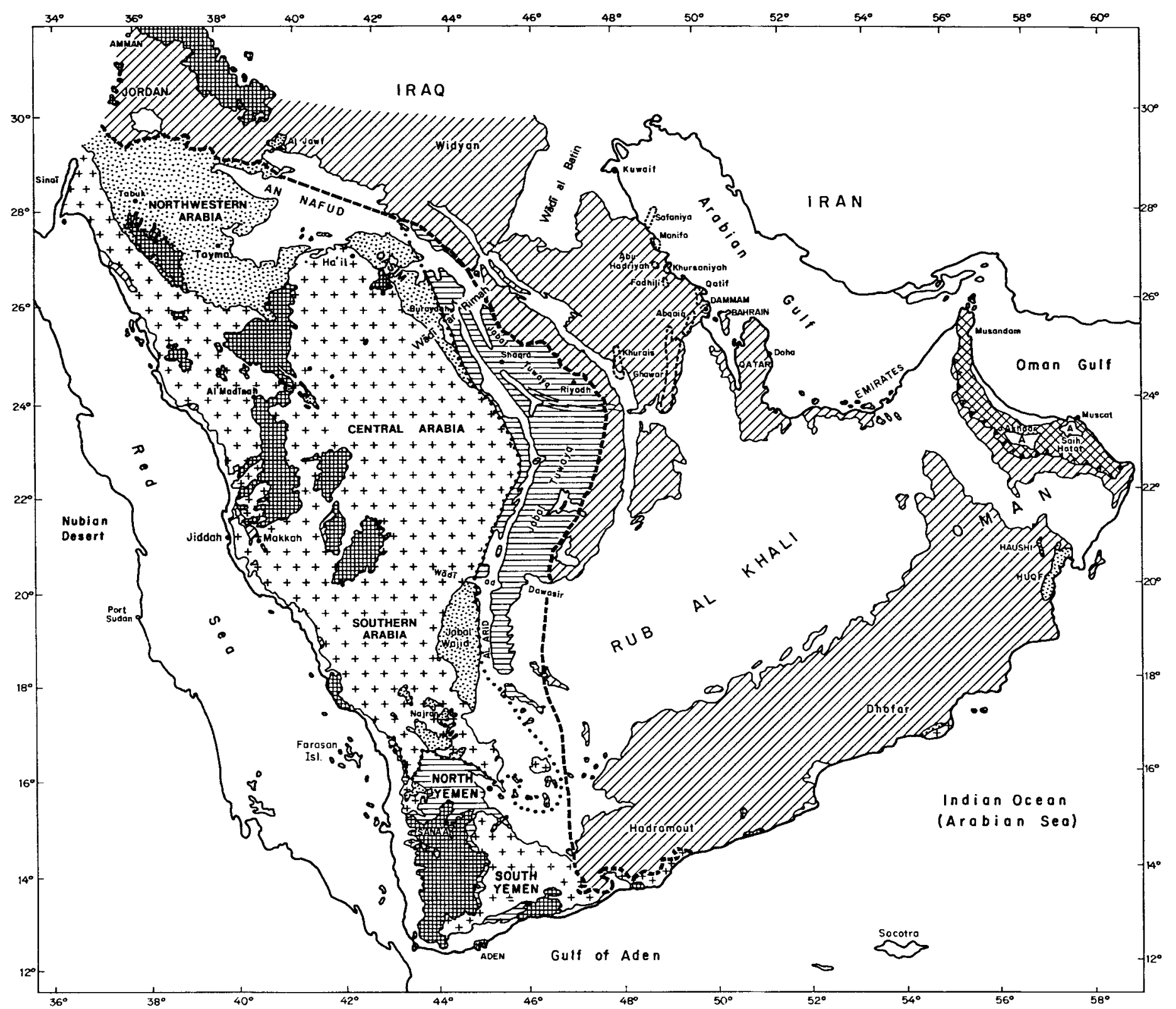

Figure 1.-Simplified geologic map of the Arabian Peninsula.

\section{EXPLANATION}

A A Oman Allochthonous front

Oman ophiolites

A Oman Autochthonous

Quaternary

Tertiary to Quaternary volcanism

DD Late Cretaceous to Tertiary

Erosion surface pre-Wasia Formation (Late Cretaceous)
Late Permian to Early Cretaceous

Erosion surface pre-Khuff Formation (Late Permian)

Paleozoic Pre-Late Permian

$+{ }_{+}^{+}$Proterozoic Shield rocks

\& Main oil fields in Saudi Arabia

$200 \quad 100 \quad 0 \quad 200 \quad 400 \mathrm{~km}$
Figure 2. - History of lithostratigraphic classification within the Paleozoic succession of Saudi Arabia and Jordan. Abbreviations: conglom., conglomerate; $f$, facies; fm., formation; gr., grained; Hamm., Hammamiyat; limest., lst., limestone; Llandov., Llandoverian; $m b$., member; Precamb., Precambrian; sh., shale; sst., sandstone; Trans., Transition. 


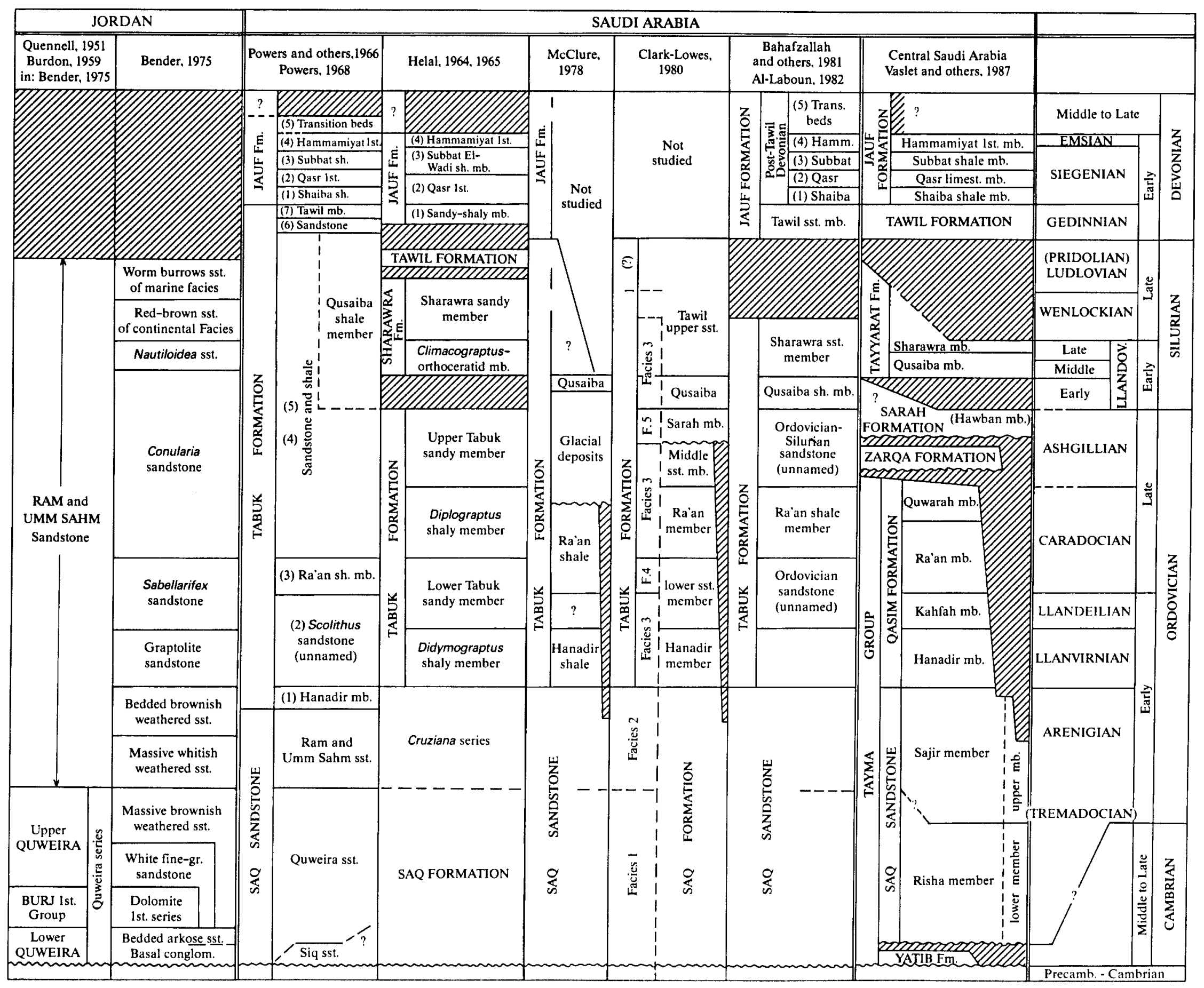




\section{Lower Paleozoic preglacial deposits}

Before the first glacial episode of Late Ordovician age, and hence below the earliest unconformity, deposits ranging in age from Cambrian(?) to Late Ordovician are represented by three formations, which are assigned to the newly named Tayma group. These formations are, from bottom to top (fig. 3), the Yatib formation, the Saq Sandstone, and the Qasim Formation.

\section{Yatib formation}

The oldest of the three formations is the Yatib formation of Cambrian(?) age (named after Jabal Yatib, Ekren and others, 1987), which overlies the Proterozoic basement with an angular unconformity and is found only west of long $42^{\circ} 15^{\prime} \mathrm{E}$. This formation occupies depressions in the paleosurface of the Shield rocks and is overlain disconformably by the Saq Sandstone. It is composed of polymictic conglomerate, the rounded clasts of which include typical Shield rocks, quartz pebbles of undetermined origin, coarse-grained sandstone, and siltstone, all set in an arenitic matrix.

\section{Saq Sandstone}

The middle of the three formations of the Tayma group is the Saq Sandstone of Cambrian(?) to Early Ordovician (Arenigian) age, a formation defined in central Saudi Arabia (Steineke and others, 1958; Powers and others, 1966; Powers. 1968). A revision of the type section is provided by Williams and others (1986) in the vicinity of Jabal Saq, where the total thickness is $663 \mathrm{~m}$. The Saq Sandstone is subdivided into two members by Vaslet and others (1985), as follows.

The lower part of the Saq Sandstone is the Risha Member (308 $\mathrm{m})$, named after $\mathrm{W}_{\bar{a} \mathrm{~d}} \mathbf{i}$ ar Risha. The member lies unconformably on rocks of the Proterozoic Shield east of long $42^{\circ} 15^{\prime} \mathrm{E}$. The base of the Risha Member consists of conglomerate of centimeter-sized, well-rounded. white quartz pebbles in a sandstone matrix. Above the conglomerate, the Risha Member consists of coarse- to fine-grained sandstone. This member is interpreted as representing a braided alluvial system that evolved upward into a deltaic system.

The Sajir Member ( $355 \mathrm{~m}$ ) is the upper part of the Saq Sandstone and is named after Wādi Sajir. It consists of medium- to finegrained sandstone interspersed with micaceous siltstone beds bearing Cruziana trails. The Sajir Member represents a prodeltaic (shallowwater) environment and contains tidal-flat deposits in its upper part. Tigillite-bearing (Scolithus) sandstone occurs discontinuously in the topmost part of the member.

\section{Qasim Formation}

The youngest of the three formations of the Tayma group is the Qasim Formation, which is named after the Al Qasim region and is of Llanvirnian to Caradocian (or Ashgillian?) age. Defined by Williams and others (1986), it lies conformably on the Saq Sandstone. The formation, which has a total thickness of $261 \mathrm{~m}$, is subdivided into four members, as follows, from bottom to top.

The oldest member of the Qasim Formation is the Hanadir Member $(26.5 \mathrm{~m})$, named after the cuesta of Al Hanadir in the Qasim region. Mainly argillaceous. the member is $48 \mathrm{~m}$ thick in a new reference section defined at At Tiniyat by Vaslet and others (1987). It contains a graptolite, trilobite, and conodont fauna of middle to late Llanvirnian age (Didymograptus murchisoni Zone). Locally, a phosphatic, bioclastic (fish debris) conglomerate occurs at the base of the member. Compared with the Saq Sandstone, the Ha- nadir Member shows a clearly transgressive character and a possible hiatus of early Llanvirnian deposition between the two units.

The next oldest member of the Qasim Formation is the Kahfah Member (104 m), defined near Al Kahfah by Vaslet and others (1987). This member is divided into two assemblages. The lower assemblage $(40 \mathrm{~m})$ consists of fine-grained, feldspathic sandstone interspersed with graptolite- and trilobite-bearing claystone of possible Llandeilian age. Locally, it contains coarse bioclastic sandstone. The upper assemblage $(64 \mathrm{~m})$ is undated and is composed of finegrained, tigillite-bearing sandstone that probably was deposited in a marine, prodeltaic environment.

The Ra'an Member (43 m) follows, defined at Ar Ra'an by Williams and others (1986). It consists mainly of claystone deposited in an outer-shelf environment, and it contains a basal graptolite (diplograptids) and trilobite (dalmanitids) fauna of possible late Caradocian age.

The youngest member of the Qasim Formation is the Quwarah Member $(87.5 \mathrm{~m})$. defined by Williams and others (1986) near Al Quwarah. It consists of alternating fine-grained (in places bioclastic) sandstone, micaceous siltstone, and claystone. This member, which makes up the upper part of the Qasim Formation, is truncated everywhere by the first glacial erosional surface (base of the Zarqa Formation) and is considered to be Caradocian(?) to Ashgillian(?) in age.

\section{Upper Ordovician glacial deposits}

Upper Ordovician glacial deposits are subdivided in central Arabia into two formations, each underlain by strong glacial unconformities: the Zarqa Formation (Vaslet and others, 1987) below and the Sarah Formation (Williams and others, 1986) above. In both formations, the glacial deposits are continental (tillite), fluvial glacial (tillite, sandstone), and glacial marine and (or) lacustrine (boulder clay, reworked tillite, slumped fine-grained sandstone). These deposits lie unconformably on rocks of the Qasim Formation, but the paleoerosion surface cuts down as far as the Saq Sandstone (fig. 4).

\section{Zarqa Formation}

The Zarqa Formation crops out in central Saudi Arabia between Asnyah (lat $27^{\circ} 55^{\prime} \mathrm{N}$., long $42^{\circ} 07^{\prime} \mathrm{E}$.) and Al Qara (lat $26^{\circ} 23^{\prime} \mathrm{N}$. long $43^{\circ} 50^{\prime}$ E.) (fig. 5). The unit unconformably overlies the Qasim Formation. which it erodes to a varied extent. The Zarqa Formation itself is channeled everywhere by the erosional surface that preceded deposition of the Sarah Formation. Located between two erosional surfaces, outcrops of the Zarqa Formation are discontinuous, and consequently the formation is nowhere fully preserved. Outcrops of the Zarqa Formation that are preserved indicate that the deposits are located in the low-lying zones of a paleotopography notched into the Qasim Formation (fig. 4). Locally, they correspond to the filling of paleovalleys, the traces of which remain visible (for example, the Ilb, Rada'if, Kuhayfi, Kahfah. and Turmus paleovalleys; see fig. 5).

The type section of the Zarqa Formation, as defined by Vaslet and others (1987), is $115 \mathrm{~m}$ thick and is located near Jal az Zarqa (fig. 5). It comprises complex interbeds of siltstone or clayey siltstone containing dropstones (boulder clay), fine-grained micaceous sandstone that commonly is slumped, and tillite. Analysis of the type section (Vaslet and others, 1987. and Vaslet, 1989) shows that the formation is made up of three main facies.

\section{Tillite facies}

Tillite 2 to $9 \mathrm{~m}$ thick is located at the bottom of the Zarqa Formation and is channeled into the underlying Qasim Formation (fig. 4). The 


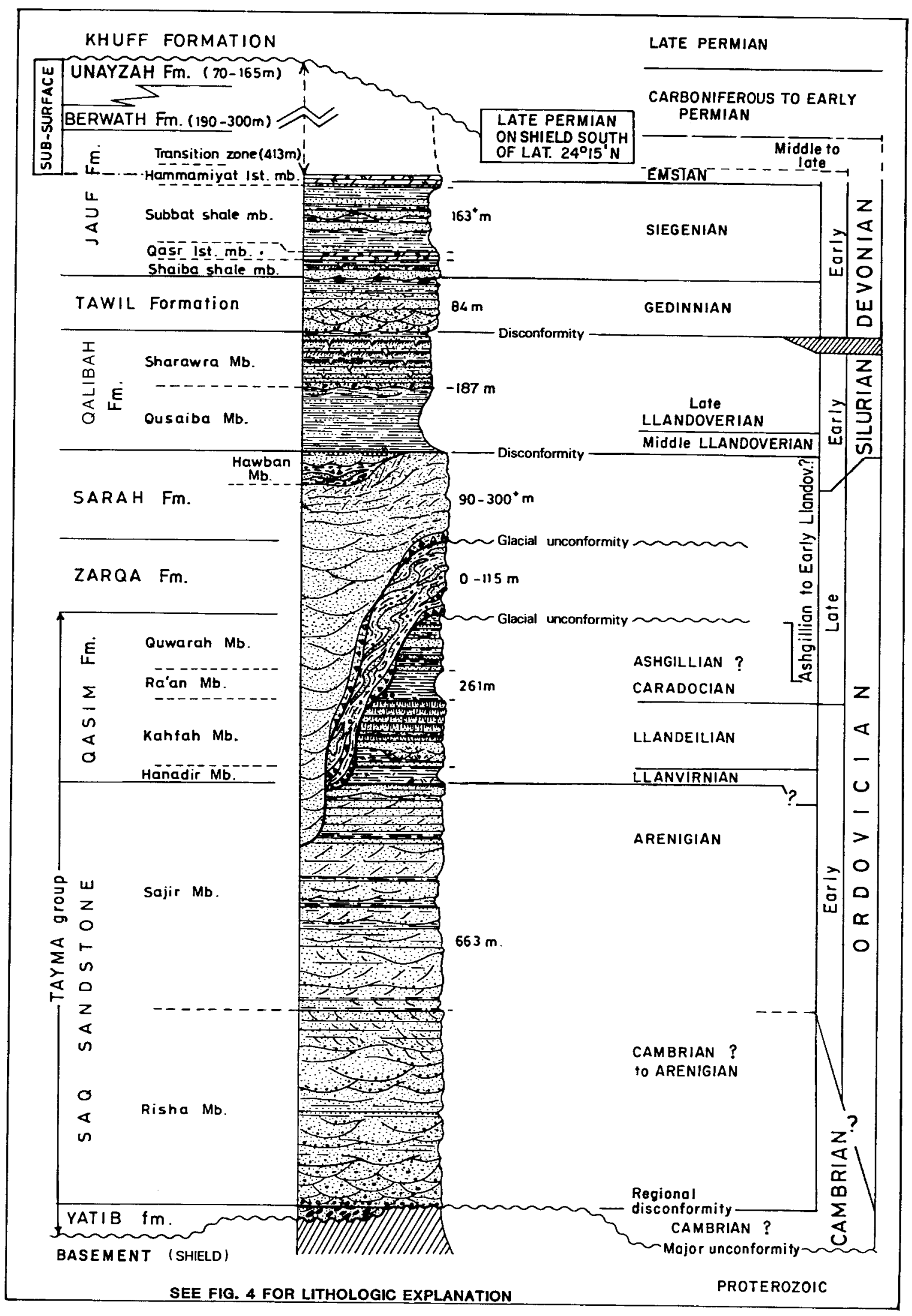

Figure 3. - The pre-Late Permian depositional succession in central Arabia. Abbreviations: fm., formation; Llandov., Llandoverian; lst., limestone; $m$, meter; mb., member. See figure 4 for explanation of symbols. 


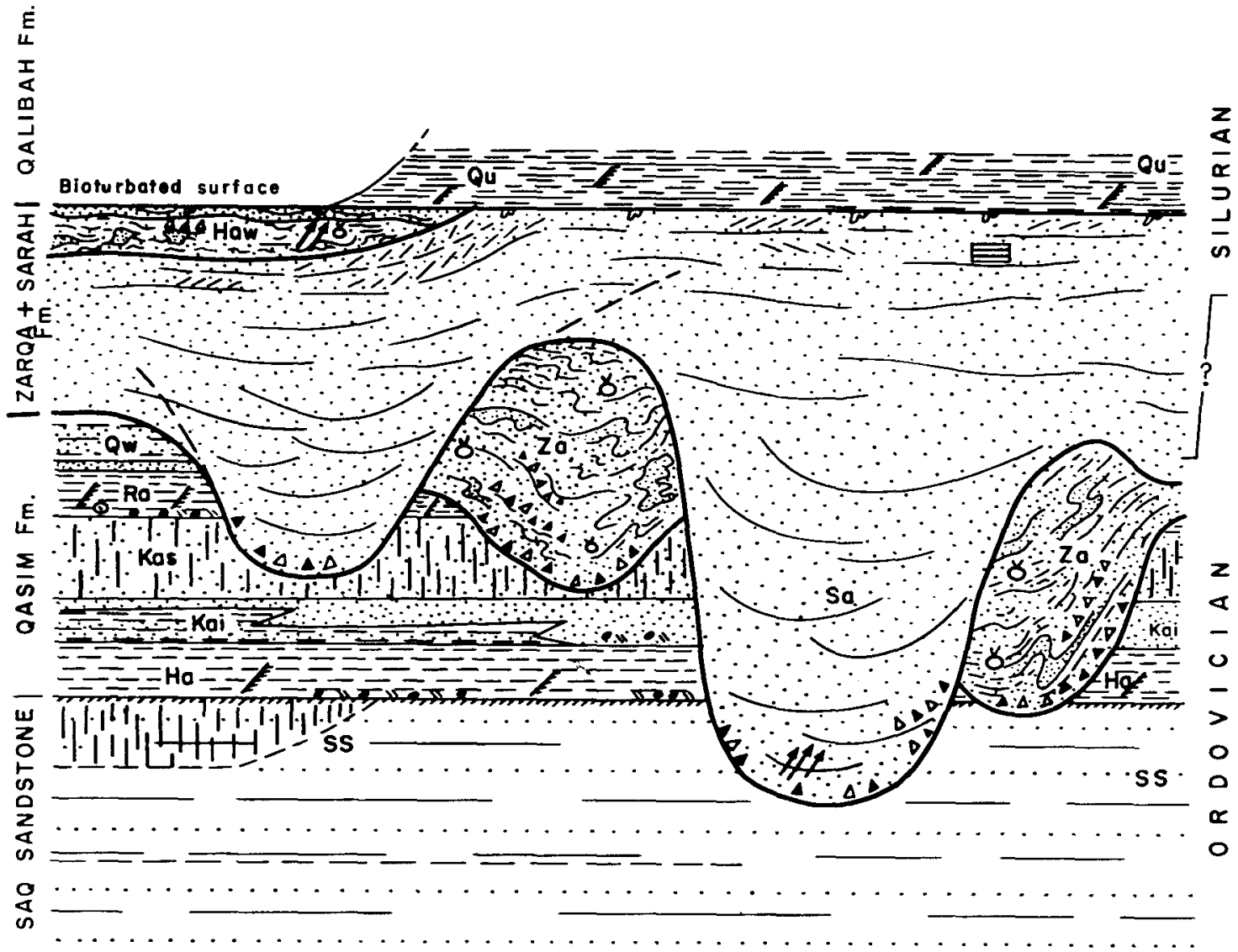

EXPLANATION

I/ Tigillites
$\cdots /$ Bioclasts
$\cdots$ Intraclasts
0 Ferruginous ooliths
$\not E$ Graptolites
rmm Bioturbated surface

$\begin{array}{ll}\Delta \Delta \Delta & \text { Tillite } \\ \text { \& } & \text { Glacial boulders } \\ \text { Af Striations, groove marks } \\ \text { G Varves } \\ \text { A Slumping } \\ \text { A Burrows }\end{array}$

Qu Qusaiba $\mathrm{Mb}$

How Hawban Mb.

Sa Sarah Formation

Za Zarqa Formation

Qw Quwarah Mb.

Ro Raian $\mathrm{Mb}$.

Kas upper $]$ Kahfah Mb.

Ho Hanadir Mb.

SS Saq Sandstone

\begin{tabular}{|c|c|c|c|c|}
\hline 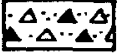 & Tillite & 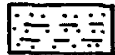 & Clayey sandstone & \\
\hline $00-0$ & Boulder clay & $\because \because$ & Sandy or silty claystone & \\
\hline$\because 0$ & Conglomerate & $==3$ & Claystone & $-100 \mathrm{~m}$ \\
\hline 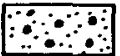 & Coarse-grained sandstone & ili: & Tigillite-bearing sandstone & \\
\hline$\because \cdots$ & Medium-grained sandstone & & & \\
\hline$\because:: \therefore$ & Fine-grained sandstone & & $\sim 5 \mathrm{~km}$ & \\
\hline
\end{tabular}

Figure 4.-Stratigraphic relationships of glacial deposits in central Arabia. Abbreviations: fm., formation; mb., nember. 


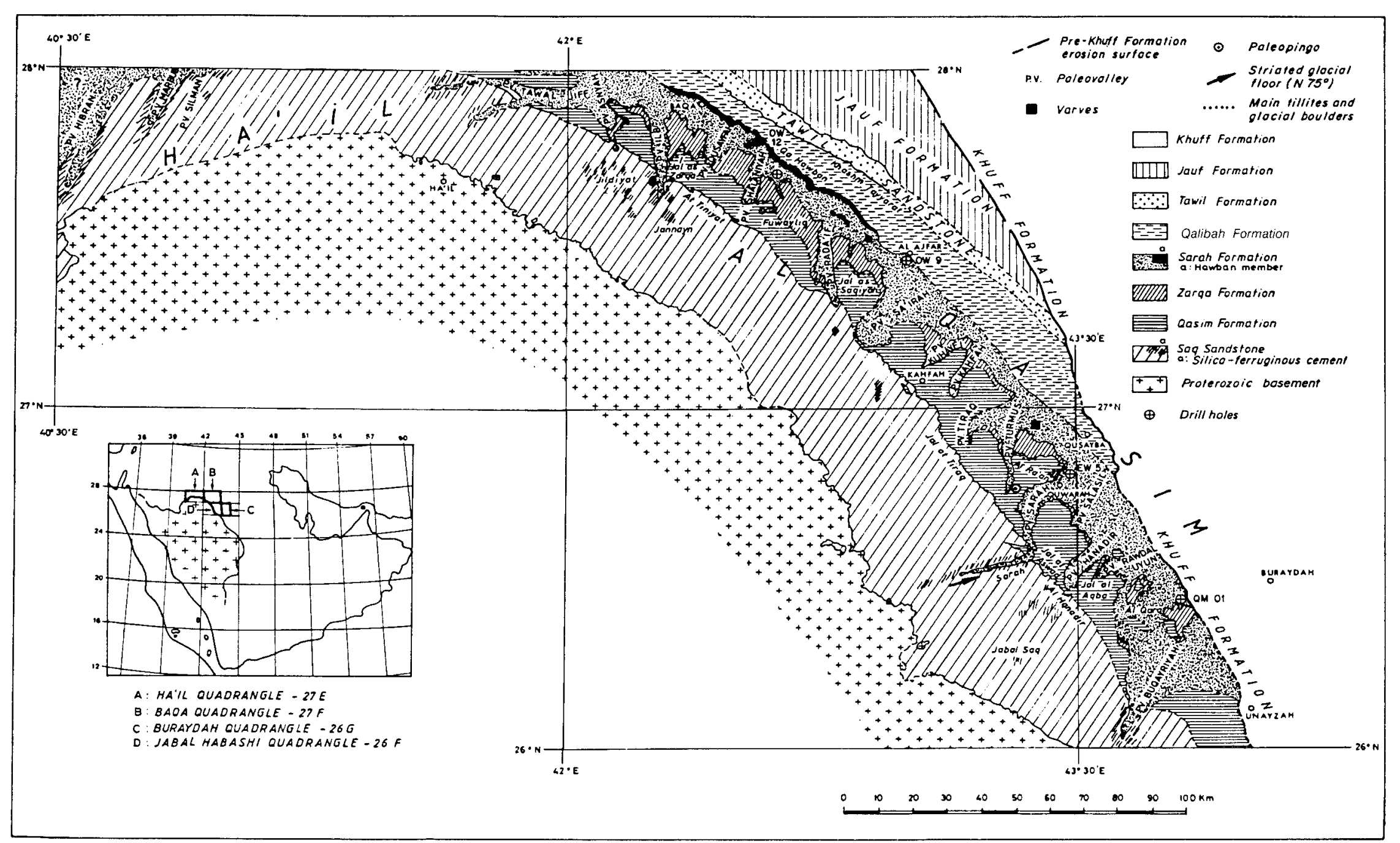

Figure 5. - Late Ordovician glacial features in central Arabia. 
tillite is composed typically of heterogenous material that includes components both from the Shield and from the sedimentary "cover" rocks that surround the Shield and that range in size from gravel to boulders up to $1 \mathrm{~m}$ in diameter (see fig. 6). Numerous pebbles and cobbles show polyhedral shapes and striated surfaces. The matrix is coarse- to fine-grained sandstone or clayey siltstone in places; it is commonly brown or is blackened by iron oxides. In places like the type section, the fine-grained boulder clay and the substratum have frost cracks that are filled with coarse tillite.

\section{Boulder-clay facies}

The boulder-clay facies comprises a very constantly dark-green, clayey, micaceous siltstone (rock flour of Beuf and others, 1971) that contains a varied proportion of pebbles, cobbles, or boulders. The clasts, in places faceted, are derived from Shield and cover rocks and represent dropstones in a mudstone facies. The faceted dropstones commonly show striated faces and range in diameter from 1 $\mathrm{cm}$ to $1 \mathrm{~m}$. Thickness variations of the facies are abrupt, such as ranging from 2 to $20 \mathrm{~m}$ thick in less than $10 \mathrm{~m}$ laterally. Variations also occur in the proportion of dropstones, which are absent in places, and in the proportion of clay and silt.

\section{Sandstone facies}

Beige, fine-grained sandstone, in places micaceous, is present as 1to 3-m-thick beds that locally are laminated and alternate with, and in places channel, the boulder clay. The beds may have a coarsegrained or conglomeratic base blackened by iron oxides. Plastic deformation, such as slumping, is nearly ubiquitous, comprising 1- to 10 -m-thick beds of sandstone slumped into the boulder clay or centimeter-sized microslumping within the sandstone itself. Other structures, such as frost wedges and polygonal ground typical of glacial environments (Beuf and others, 1971), are also present in the sandstone.

\section{History of deposition}

The Zarqa Formation consists of glacial features and continental deposits succeeded by subaquatic deposits that are either lacustrine or shallow marine in origin. The topmost part of the formation displays predominantly a marine character, as in the case of laminated sand-

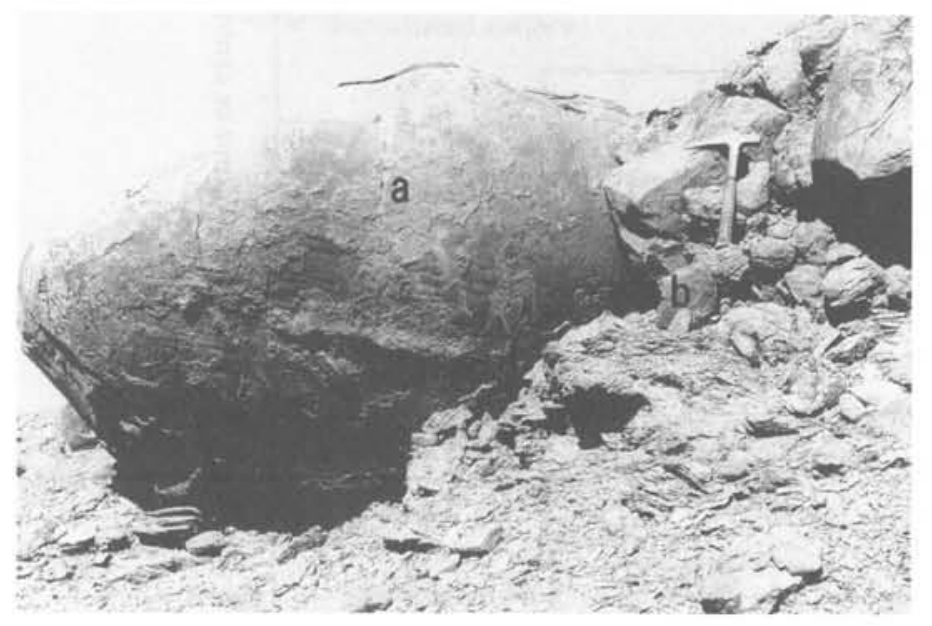

Figure 6.-Tillite at the base of the Zarqa Formation near At Tiniyat showing a boulder of striated sandstone (a) and a polyhedral, faceted basement cobble (b). stone interpreted to be intertidal deposits. The Zarqa Formation deposits can be interpreted, respectively, as remnants of glacial moraines in the case of the continental deposits and as subglacial or proglacial subaquatic deposits into which erratic components were released by drift ice in front of the glacier. The ice also may have been responsible for the intense plastic deformation (slumps) that occurred while these sediments were saturated with water. Additionally, wells in the Zarqa Formation have yielded an Ordovician microflora similar to that encountered in the underlying Qasim Formation.

\section{Sarah Formation}

Outcrops of the Sarah Formation in central Saudi Arabia (fig. 5) are located between the southeast edge of the Great Nafud (An Nafud) and Wādī ar Rimah, the main tributary to Wādī al Batin near Buraydah (fig. 1). They form a northwest-trending belt of irregular width, and they take one of the following two forms. (1) At the north and northeast edges of the belt, the outcrops appear to be continuous, although they are interrupted by substantial Tertiary and Quaternary cover, particularly around the large consequent wadis. (2) At the south and southwest edges of the belt, the Sarah Formation crops ou in the form of elongate, bar-type relief features that are oriented perpendicular to the general alignment of the formation. These bars, in places up $50 \mathrm{~km}$ long and between several hundred meters and several kilometers wide, represent the filling of paleovalleys, so the original low relief is now reversed. A total of 19 main paleovalleys has been distinguished and named after local features (the Sarah paleovalley, the Turmus paleovalley, and so on, fig. 5).

The flow direction of the paleovalleys ranges from eastward to northward, the preferential average flow being northeastward. The paleovalleys systematically broaden downstream (that is, roughly northeastward) and become coalescent, so that they form a continuous outcrop belt. The Sarah Formation is bounded at the base by a major unconformity and lies on an erosional surface cut deeply into the Saq Sandstone, the Qasim Formation, and the Zarqa Formation. The upper boundary of the Sarah Formation is marked by a disconformity with the overlying marine claystone of the Qusaiba Member of the Qalibah (Tayyarat) Formation (fig. 4).

The Sarah Formation, defined at Khanasir Sarah by Williams and others (1986), is essentially sandy and relatively uncemented, except in the lower part of paleovalleys where tillite is preserved locally. To the north between Al Ajfar and Baq'a, a local facies of glacial to marine origin, known as the Hawban Member (Vaslet and others, 1987), gives rise to a cuesta in the upper part of the formation (figs. 3-5).

Although the residual thickness of the Sarah Formation is only $27 \mathrm{~m}$ in the type section at Sarah, the unit is locally over $300 \mathrm{~m}$ thick in the downstream axial part of the paleovalleys (Vaslet, $1987 \mathrm{a}, \mathrm{b}$, and c). The formation shows a minimum of $90 \mathrm{~m}$ of sedimentary rock where the formation crops out continuously outside the paleovalleys. The Sarah Formation is composed mainly of mediumto fine-grained sandstone accompanied at the edges and at the bottom of the paleovalleys by tillitic rocks very similar to those of the Zarqa Formation. In the new reference section described by Vaslet and others (1987) and Vaslet (1989), which is above the type section of the Zarqa Formation in the Baq'a area, the formation is $139 \mathrm{~m}$ thick and includes the type section of the Hawban Member ( $54 \mathrm{~m}$ ).

\section{Morphologic features}

As in the case of the Zarqa Formation, a number of structures, shapes, and facies that are characteristic of a glacial or periglacial environment mark the Sarah Formation. The following are the most significant of those morphologic features. 


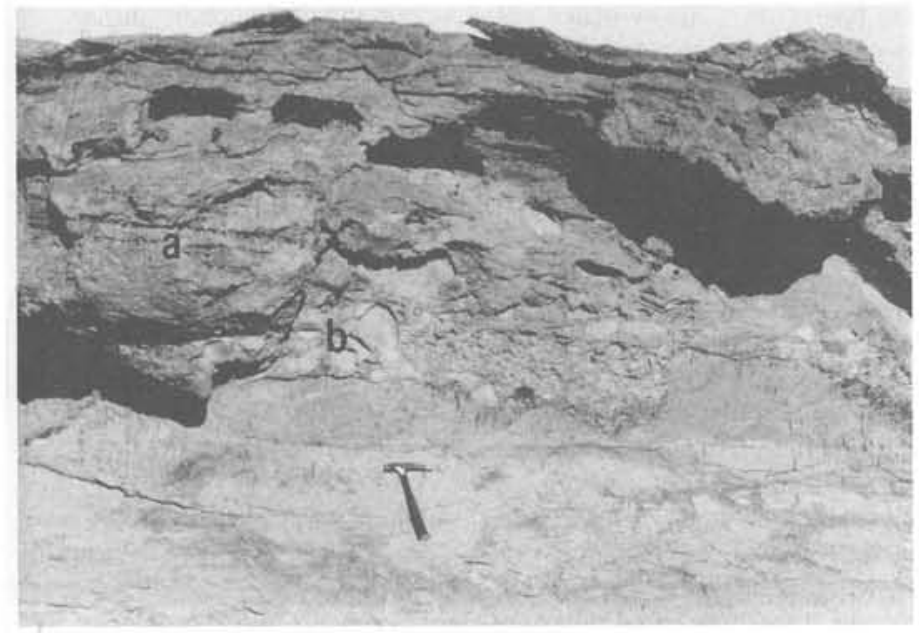

Figure 7.-Tillite at the base of the Sarah Formation on tigillite-bearing sandstone of the Qasim Formation near Rawd al Uyun showing a polyhedral basement cobble (a) and a boulder of tigillite sandstone (b).

(1) Tillite (fig. 7) is present locally at the base of the paleovalleys, particularly at the present-day margins rather than at the bottom, where it appears to have been eroded during the deposition of sedimentary fill. This tillite displays all stages of evolution from continental tillite (at Rawd al Uyun and Al Quwarah) to tillite reworked in a subaquatic environment (at Rawd al Uyun and Silman; see locations in fig. 5). Polyphase episodes, such as the alternation of tillite and sandstone in the lower $10 \mathrm{~m}$ of the formation near Rawd al Uyun, may represent stages of seasonal advance and retreat of the ice.

(2) Glacial floors (fig. 8A) appear in the lower part of the Sarah paleovalley, as at Khanasir Sarah. Here, a grooved floor has been spared from further erosion over a distance of $26 \mathrm{~m}$ because of later ferruginous cementation and the very recent removal of overlyingmaterial. At this locality, parallel striations and grooves are oriented $\mathrm{N}$. $75^{\circ} \mathrm{E}$. and occur over the entire length of the grooved floor. In addition, concave pluck structures, crescent-shaped fractures, and a sinuous ice groove (fig. $8 B$ ) are seen. Similar ice groove structures described by Dionne (1985) in present-day Canadian periglacial facies indicate the relative plasticity of material during passage of the ice.

(3) Striated and grooved roches moutonnées protrude over the Saq Sandstone and the Zarqa Formation or remain within the Sarah Formation itself, either in the lower part of the paleovalleys or in the Hawban Member.

(4) Rock slides are evident. For instance, large parts of the Hanadir Member of the Qasim Formation slid to the bottom of the paleovalleys, where they are preserved as distorted masses.

(5) Slumps of sandy material are found in the Sarah Formation, such as the sandstone of the Hawban Member.

(6) The presence of erratic blocks in the Hawban Member indicates that they were dropped into the boulder clay of the member.

(7) Laminated, varvelike rocks occur in the upper part of the Sarah Formation.

(8) Hydrolaccoliths, or pingos, are known in present-day periglacial areas of the Arctic (Maarleveld, 1965). These features are caused by the elevation and deformation of upper layers of frozen ground (permafrost) due to the pressure of an underlying water pocket that has been transformed into a lens of ice. Several paleopin- gos $100 \mathrm{~m}$ in diameter were discovered by the author in the lower part of the Sarah Formation near Tayma in northwestern Arabia (fig. 1).

A large (300 $\mathrm{m}$ in diameter), perfectly fossilized paleopingo rests on the Qasim Formation in central Arabia (fig. 9). It is a circular depression that is $100 \mathrm{~m}$ wide and surrounds a central, steepsided, and uplifted center. The core of this feature contains rocks of the lower unit of the Kahfah Member of the Qasim Formation. These rocks, consisting of argillite and bioclastic sandstone that contain fish debris, have been affected by intense plastic deformation. This paleopingo, located close to a paleovalley in the Sarah Formation, is thought to be related to a later glacial event.

\section{History of deposition}

The development of the Sarah Formation paleoenvironment is interpreted as follows. Initially, the lower part of the Sarah Formation, which channels the Zarqa Formation and its substratum, was deposited in very deeply cut paleovalleys that had flat bottoms and slightly inclined sides. The sides of these paleovalleys locally show roches moutonnées, grooves, and pockets in which tillite is preserved, and the paleovalleys are interpreted to be glacial in origin. Because of the strong secondary cementation that affected the porous material at the bottom of the paleovalleys and in the substratum, these paleovalleys are now in reverse relief.

The filling in the paleovalleys is very homogeneous (mediumgrained, crossbedded sandstone) and is fluviatile or fluvial marine in character. Layers of reworked tillite locally alternate with the sandstone, and a striated glacial floor occurs in the lowest few meters of sedimentary rocks in some paleovalleys. These factors indicate the presence and activity of ice, temporarily anyway, when the paleovalleys began to be filled. Therefore, at least some of the fill sediments are proglacial in character. Such fluvial-glacial sediments channeled the earliest tillite, and probably also the earliest glacial deposits, that is preserved only in pockets on the flanks and bottom of the paleovalleys.

The upper part of the Sarah Formation overflowed the paleovalleys and covered much of central Saudi Arabia with sandstone that was no longer directly glacial in origin. However, it represents subaquatic sedimentation in which the traces of a periglacial lacustrine environment (varves) persist locally and in which a marine character is increasingly predominant. This thick and voluminous detrital sedimentation may have resulted from an episode of a general thawing that liberated the huge amount of sandy material stored in the ice. This sandy material resulted from the cutting of paleovalleys in essentially sandy formations such as the Saq Sandstone and the Qasim Formation.

The Hawban Member of the Sarah Formation is locally (between Al Ajfar and Baq'a; see fig. 5) indicative of a new glacial environment at the top of the Sarah Formation. It is characterized by roches moutonnées and grooved glacial surfaces, tillite, boulder clay, and bedded sandstone, which became marine at the top. The member may represent a final advance of the ice over central Saudi Arabia after deposition of the Sarah Formation and before (or, in the case of the upper part of the member, simultaneously with) a return to true marine conditions. These marine conditions are represented by the clays at the base of the overlying Qusaiba Member of the Qalibah (Tayyarat) Formation, which contain Silurian graptolites. The passage of the ice would have been responsible for the deformation that is observed at the top of the Sarah Formation (glaciotectonic deformation).

The microflora encountered in wells that cross the Sarah Formation in the Qasim region indicates the appearance of an Early Silurian association of acritarchs and chitinozoans toward the upper part of 


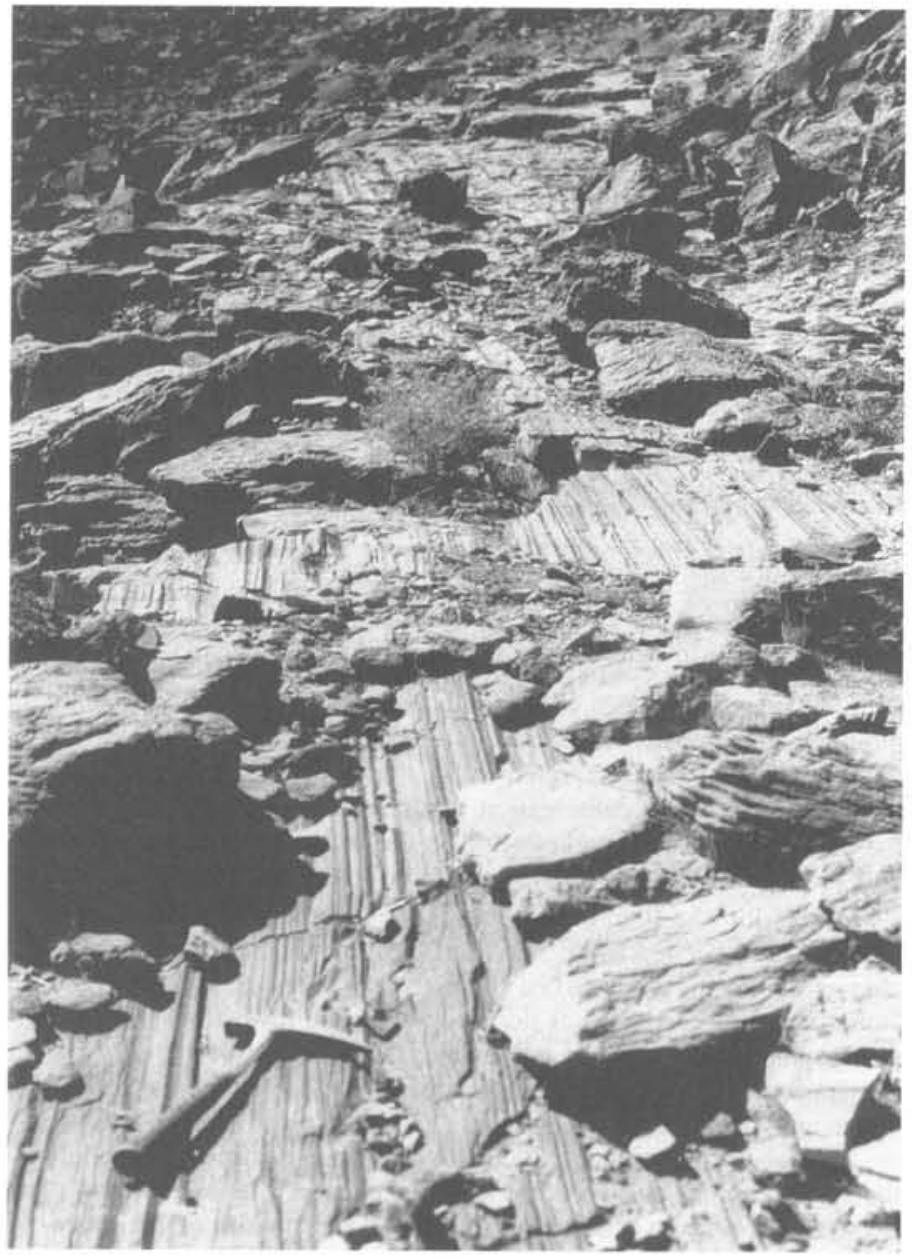

$A$

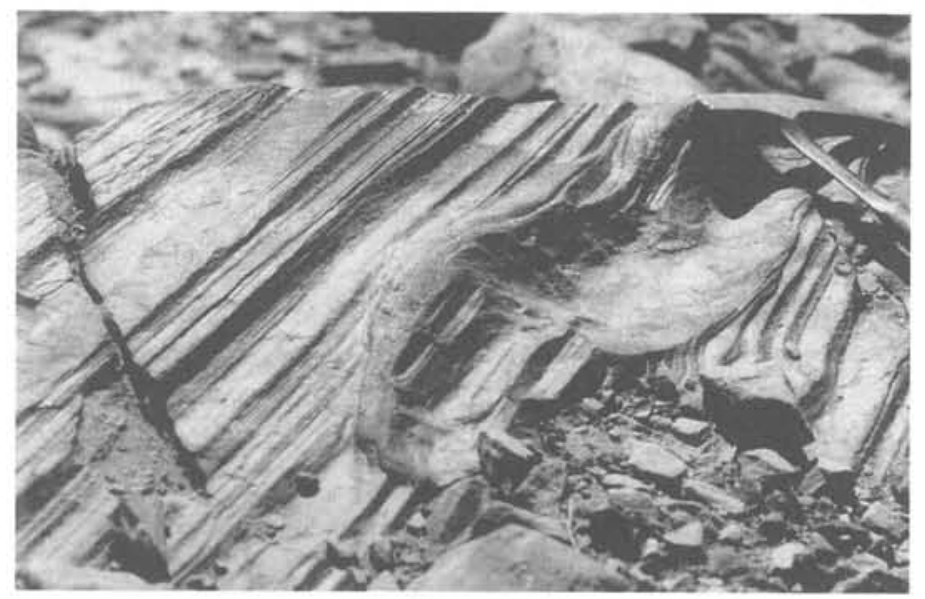

$B$

Figure 8.-Glacial features in the Sarah Formation. A, Grooved and striated glacial pavement in the lower part of the Sarah Formation at Khanasir Sarah. B, Sinuous ice groove and the surrounding ridge, a detail from the glacial pavement pictured in $\mathbf{A}$. the formation. This evidence suggests that the Ordovician-Silurian boundary is possibly located within the formation.

\section{Lower Paleozoic postglacial deposits}

The lower Paleozoic glacial deposits in central and northwestern Arabia are overlain disconformably by Llandoverian transgressive marine deposits (figs. 2, 3, and 4). Previously described as the "Tay. yarat Formation" by Vaslet and others (1987), this Llandoverian unit will be redefined as the "Qalibah Formation" (D. Mahmoud, D. Vas. let, and M.I. Husseini, unpublished data) on the basis of new subsurface and surface reference sections.

The Qalibah Formation (alias Tayyarat Formation) includes two members. The lower member is the Qusaiba Member, as redefined by Manivit and others (1986). It is predominantly clayey, which indicates deposition in an outer-shelf environment, and it is interspersed with siltstone and micaceous, fine-grained sandstone layers in its upper part. In central Arabia, the basal part of the Qusaiba Member contains a rich graptolite fauna of middle Llandoverian age (Monograptus fimbriatus Subzone, Monograptus convolutus Zone) (Vaslet and others, 1987, after P. Legrand, written commun., 1984; El-Khayal, 1985, 1987; McClure, 1988). However, preliminary investigations in northwestern Arabia demonstrate an early Llandoverian graptolite association (P. Legrand, written commun., 1989) from the clayey basal part of the Qusaiba Member that directly overlies the sandy facies of the Sarah Formation. A similar diachronism of transgressive marine rocks has been demonstrated by Legrand (1985) in the basal Silurian rocks of southern Algeria (Hoggar Mountains).

The upper part of the Qalibah Formation is the Sharawra Member (Vaslet and others, 1987), which mainly consists of sandy marine strand deposits containing surface-type sequences and thin conglomerate layers at the base. Devoid of characteristic fossils, this member is assumed to be late Llandoverian in age on the basis of comparison with surface data (Al-Laboun, 1982, 1986).

The Llandoverian rocks of the Qalibah (alias Tayyarat) Formation are, in turn, overlain disconformably by a braided-stream, alluvial sandstone unit (Tawil Formation) of probable Early Devonian age (Bahafzallah and others, 1981; Al-Laboun, 1982, 1986). Consequently, Upper Silurian deposits are unknown in central Arabian outcrops.

\section{Distribution of lower Paleozoic glacial deposits in Saudi Arabian outcrops}

Reconnaissance work in northwestern Arabia (D. Vaslet, A. Berthiaux, and Y.-M. Le Nindre, unpublished data) has shown that glacial deposits, including both the Zarqa and Sarah Formations, are also well represented throughout the Tabuk area (fig. 1) as far north as the Jordanian border. Here, the glacial unconformities show the same features as those in central Arabia and comprise long and narrow paleovalleys cut deeply into the Qasim Formation and Saq Sandstone equivalents. The paleovalleys indicate flow directions to the north and northeast (fig. 10).

Below the glacial formations, the same four members of the Qasim Formation can be distinguished in northwestern Arabia. They show similar rock types and thicknesses, except for the Quwarah Member, which is slightly thicker here than it is farther southeast. Above the glacial formations, Lower Silurian deposits are also similar to those in central Arabia, even though they are considerably 


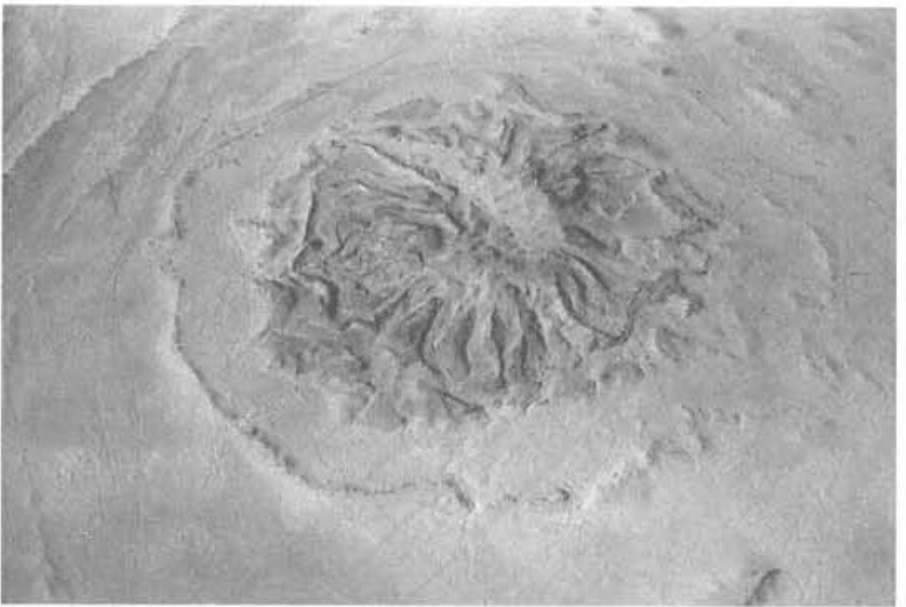

Figure 9. -Aerial view of paleopingo approximately $300 \mathrm{~m}$ in diameter found south of Wādi al Nakhrim in central Arabia.

thicker. This area has been retained for the new reference section of the Qalibah Formation (D. Mahmoud, D. Vaslet, and M.I. Husseini, unpublished data).

The presence of lower Paleozoic glacial deposits in southern Saudi Arabia (Jabal Wajid area, fig. 1) is less well documented than in the central part of the Kingdom. In the south, McClure (1980) assigned a Cambrian to Late Ordovician age to the exposed part of the Wajid Sandstone, described as "Lower Permian and ?older" by Powers (1968).

The north part of the Wajid Sandstone was mapped more recently by Kellog and others (1986), who subdivided it into four members. The second and fourth (uppermost) members, the Sanamah and Juwayl Members, respectively, show strong erosion at their bases, as well as sedimentary features that might indicate deposition in a periglacial environment. Vaslet (1989; fig. 3) proposed correlating this uppermost member with the Sarah Formation. However, more recent field investigations by the author and an Aramco team of geologists demonstrated that the Sanamah Member cropping out at Jabal Wajid is strictly equivalent to the Sarah Formation of central Arabia and indicates (glacial pavements, paleovalleys) a northward direction of ice movement during Late Ordovician time. In this southern area, the Ordovician glacial deposits are directly overlain by fish-bearing Devonian sandstone, and the top unit (Juwayl Member) represents Permian-Carboniferous glacial deposits.

\section{Correlations between Arabia and neighboring regions during Late Ordovician glaciation}

$T_{\text {races of the Late Ordovician glaciation were first described in the }}$ Hoggar Mountains region of southern Algeria by Beuf and others (1966, 1971), Rognon and others (1972), and Biju-Duval (1974), and they were described subsequently in western Africa by Deynoux (1980, 1985). Many other studies undertaken since then in northern and western Africa are included in compilations by Deynoux and others (1985), Destombes and others (1985), and Legrand (1985).

Between the Hoggar region and Arabia, evidence of glacial or periglacial sequences of Late Ordovician age is recorded (fig. 10) in the Fezzan region and in the Murzuk and Homra basins of Libya
(Bellini and Massa, 1980; Klitzsch, 1981); in Djado, Libya (Deynoux and others, 1985); and on the west and east (Jabal Awaynat) flanks of the Kufra basin of Libya (Bellini and Massa, 1980). The presence of glacial deposits at the south edge of the Kufra basin (at Ennedi and Erdis in Chad) is not demonstrated. In Egypt, Issawi and Jux (1982) described possible fluvial-glacial deposits, including dropstones, in the Sinai, the Northeastern Desert, and the Southeastern Desert. No evidence of glacial episodes is described in Jordan (Bender, 1975; Wolfart, 1981) but possibly should be sought in the Conularia Sandstone, the upper part of which contains Ashgillian trilobite faunas (Wolfart and others, 1986). Nonetheless, it appears probable that this glaciation affected at least the south of Jordan, such deposits having been recognized by the present authors as far as the border between Saudi Arabia and Jordan. The presence of Upper Ordovician glacial deposits is also cited in Ethiopia by Saxena and Assefa (1983), but this area is still under controversy owing to the presence of both early and late Paleozoic glacial events.

The early Paleozoic geodynamic evolution of Arabia clearly belongs to the broader paleogeographic context of the Gondwana paleocontinent and its margins. Given the amplitude of the continental ice sheet in relation to the Gondwana paleocontinent as a whole, the Arabian and south Libyan ice sheets probably should be assigned to the same Late Ordovician glacial events. This concept is not contradicted by the paleolatitudes indicated by Smith and others (1981), who position central Arabia between lat $55^{\circ}$ and $60^{\circ} \mathrm{S}$. (that is, by comparison with present-day geography, between Tierra del Fuego and Ross Island in the Southern Hemisphere). Nor is this concept contradicted by the hypothesis of an ice pole located to the south of the Sahara (Beuf and others, 1971; Deynoux, 1980), central Arabia being positioned toward lat $50^{\circ} \mathrm{S}$.

To the north and northeast of Arabia, a Gondwanian marine fringe is represented by Ashgillian, fairly uniform marine sedimentation, including coarse- to fine-grained sandstone, siltstone, and argillite, in Turkey (Brinkmann, 1976), in Iran (Stöcklin, 1972; Wolfart, 1981), in northern Syria (Brinkmann, 1976; Fontaine, 1981), and in the Oman mountains (Lovelock and others, 1981; Le Métour, 1988).

As in Saudi Arabia, the glacial event in the Hoggar Mountains region of southern Algeria (Beuf and others, 1971) is dated from late Caradocian onward. These authors proposed a depositional zonation. They showed that the continental glacial deposits were centered on the present-day Hoggar massif and its immediate periphery, whereas continental or marine periglacial deposits were distributed further north in Honrra, Tripolitania. A zonation of this type cannot be defined on the basis of outcrops in Saudi Arabia, but marine glacial deposits nonetheless predominate over continental glacial deposits there.

A polar projection of the Southern Hemisphere during Late Ordovician time (fig. 11) shows the direction of glacial movements according to previous work in northern and western Africa (Beuf and others, 1971; Destombes and others, 1985; Deynoux and others, 1985 ) and in southern Africa (Rust, 1981; Spjeldnaes, 1981). Taken in conjunction with new data from Saudi Arabia, this work indicates the approximate boundaries of the Late Ordovician icecap that covered a large part of the Gondwana paleocontinent. Furthermore, the average northeast-flow directions of the ice in Saudi Arabia support the hypothesis of an ice pole located at that time in central Africa.

\section{Conclusions}

In Saudi Arabia, the Late Ordovician glaciation is marked by several episodes of advance and retreat of the icecap that developed on the Gondwana paleocontinent. Two major extensions of the ice over 


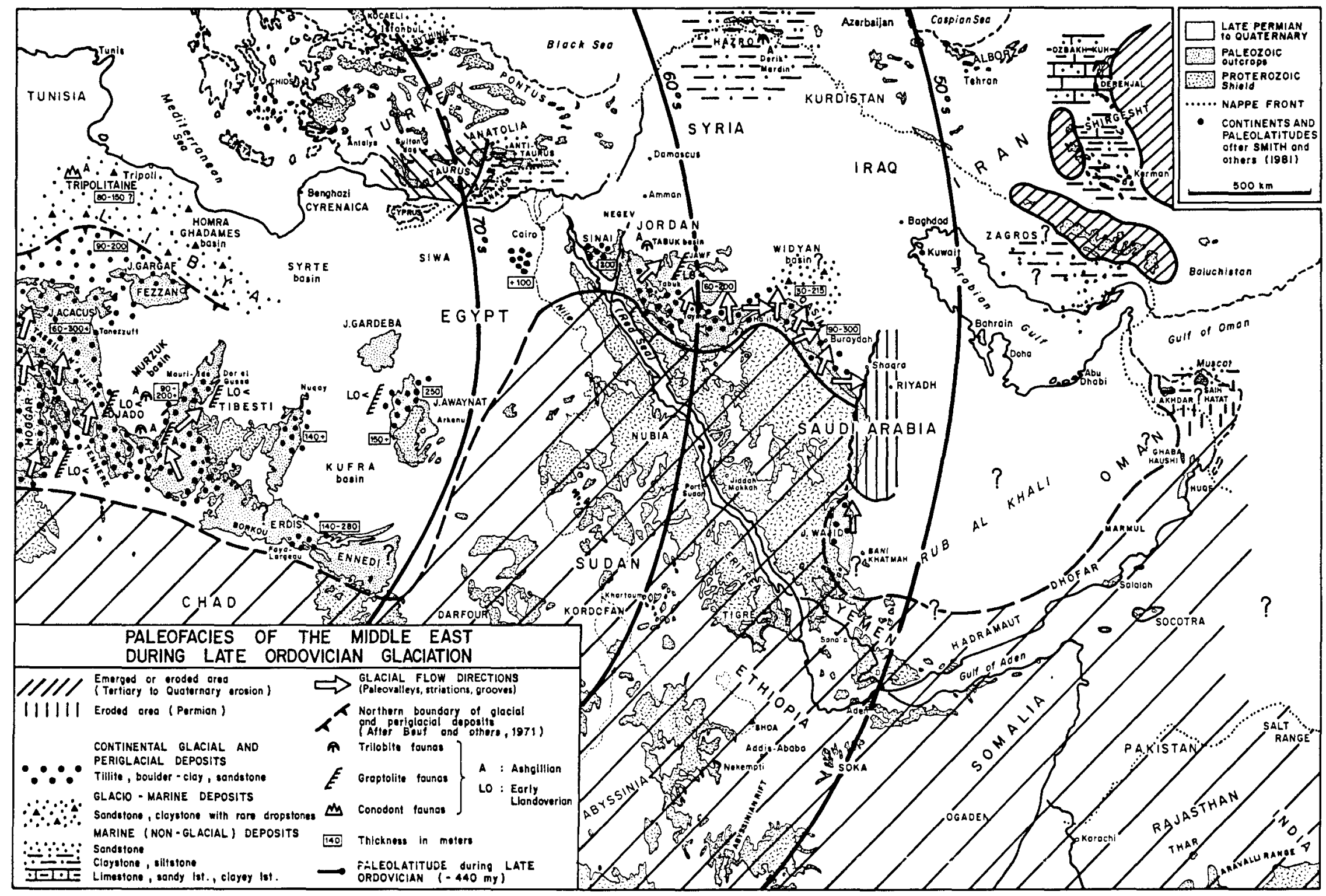

Figure 10. - Paleofacies of the Middle East during Late Ordovician glaciation. Abbreviations: J., Jabal; Ist., limestone; my, million years. 


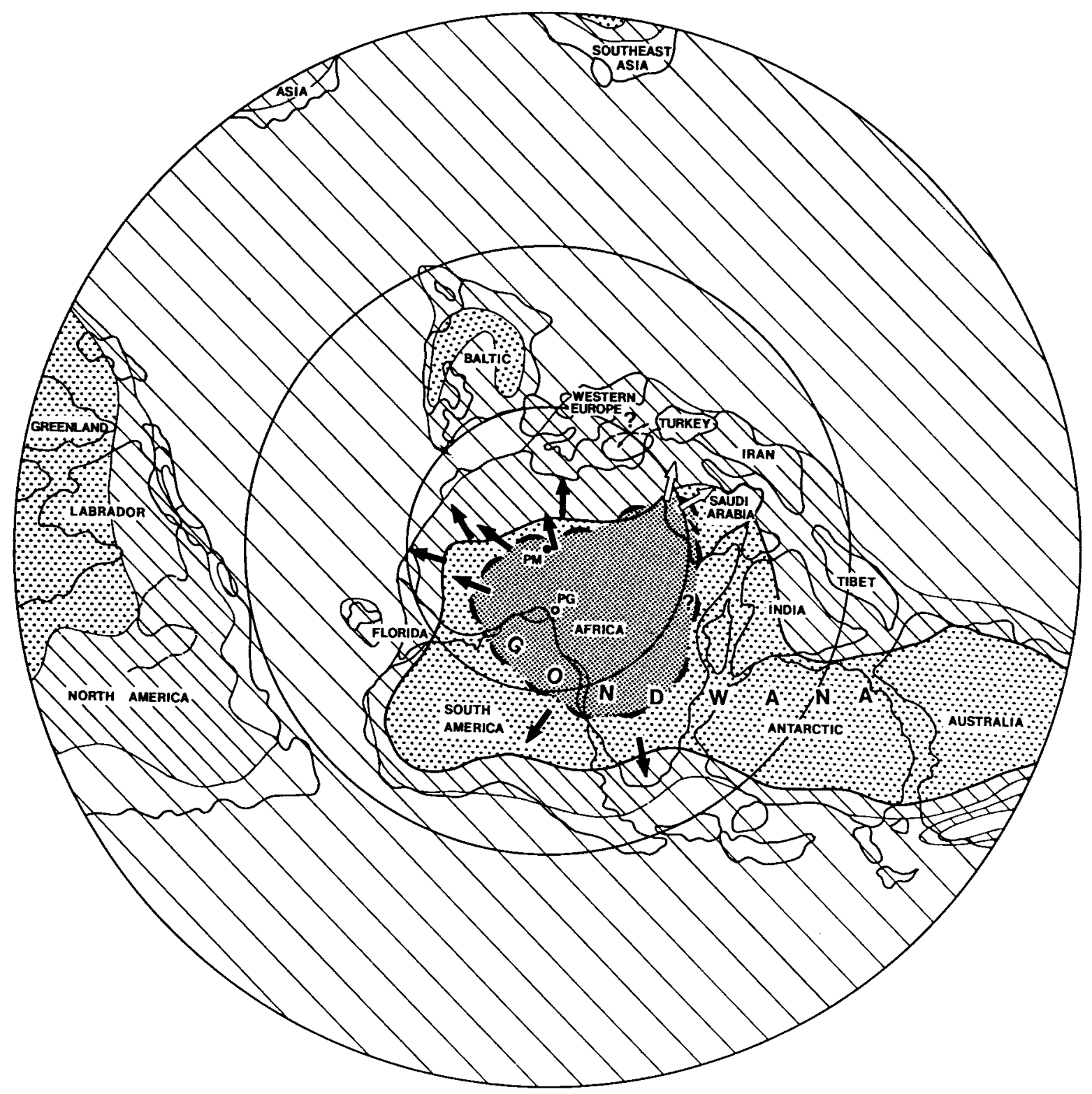

EXPLANATION

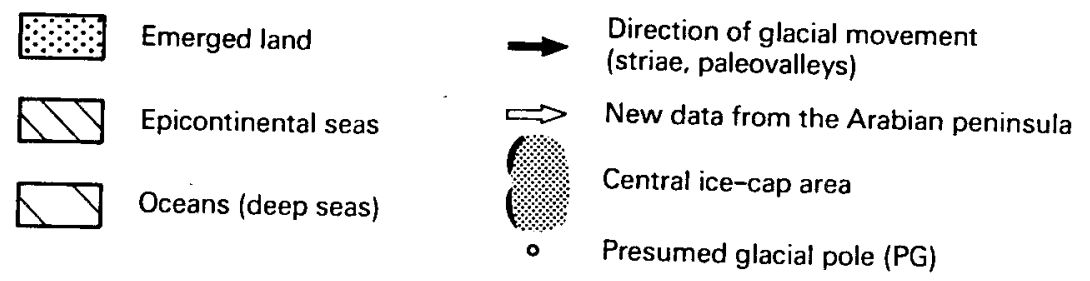

Figure 11.-Polar projection of the Southern Hemisphere during the Late Ordovician at approximately 430 Ma. The positions of the continents and magnetic pole are interpreted and modified from Scotese and others (1979), Smith and others (1981), and Crowell (1981). Geologic data from outside the Arabian Peninsula are from Beuf and others (1971), Destombes and others (1985), Deynoux and others (1985), Caputo and Crowell (1985), and Spjeldnaes (1981). Abbreviations: PM, magnetic pole; Ma, Mega-annum, $10^{6}$ years. 
the Arabian Peninsula are recorded by two major erosional surfaces and subsequent glacial and periglacial, continental to subaquatic deposits, as well as by typical features that indicate an average ice-flow direction toward the northeast. Secondary glacial phases took place within each major episode. After the melting of the ice, which probably retreated in a single but oscillating process, the Early Silurian marine transgression appears to have been slightly diachronous at the scale of the Arabian Peninsula. This diachronism also is recorded in other northern areas of Gondwana.

\section{References}

Al-Laboun. A.A., 1982, The subsurface stratigraphy of pre-Khuff formations in central and northwestern Arabia: Jiddah. King Abdulaziz University, Ph.D. thesis, $102 \mathrm{p}$.

1986. Stratigraphy and hydrocarbon potential of the Paleozoic succession in both Tabuk and Widyan basins. Arabia, in Halbouty, M.T. ed.. Future petroleum provinces of the world: American Association of Petroleum Geologists Memoir 40, p. 373-397.

Bahafzallah, A., Jux, U.. and Omara, S., 1981. Stratigraphy and facies of the Devonian Jauf Formation. Saudi Arabia: Neues Jahrbuch für Geologie und Paläontologic Monatshefte, v. 1, p. 1-18.

Bellini, E., and Massa, D.. 1980. A stratigraphic contribution to the Paleozoic of the Southern Basins of Libya, in Salem. M.J., and Buswell, M.T., eds.. Geology of Libya: London, Academic Press, p. 1-56.

Bender, F., 1975. Geology of the Arabian Peninsula: Jordan: U.S. Geological Survey Professional Paper 560-I, 36 p.

Bcuf, S., Biju-Duval, B.. Charpal, O. de, Rognon, P.. Gariel, O., and Bennacef. A., 1971, Les grès du Paléozoique inféricur au Sahara: Editions Technip. Institut Français du Pétrole. Science et Technique du Pétrole. no. $18.464 \mathrm{p}$.

Beuf, S., Biju-Duval, B.. Stevaux. J.. and Kulbicki. G., 1966, Ampleur des glaciations "siluriennes" au Sahara. leurs influences et leurs conséquences sur la sédimentation: Revue de l'Institut Français du Pétrole, v. XXI. p. $363-381$.

Biju-Duval. B.. 1974, Exemples de dépôts fluvio-glaciaires dans l'Ordovicien supérieur et le Précambrien supérieur du Sahara central: Société Nationale des Pétroles d'Aquitaine (SNPA), Bulletin du Centre de Recherches de Pau. v. R. p. 209-226.

Bramkamp. R.A.. Ramircz. L.F., Brown, G.F., and Pocock, A.E., 1963. Geologic map of the Wadi ar Rimah quadrangle, Kingdom of Saudi Arabia: U.S. Geological Survey Miscellaneous Gcologic Investigations Map I-206 A. scale 1:500.000

Brinkmann, R., 1976, Geology of Turkey: Amsterdam. Elsevier, 158 p.

Caputo, M.V.. and Crowell, J.C., 1985, Migration of glacial centers across Gondwana during Palcozoic Era: Geological Society of America Bulletin, v. 96, p. $1020-1036$.

Clark-Lowes. D.D., 1980. Sedimentology and mineralization potential of Saq and Tabuk formations: London. Imperial College of Science and Technology, Cover Rock Contract Open-File Report CRC/IC 7 and Saudi Arabian Directorate General of Mineral Resources Open-File Report DGMR-767.88 p.

Crowell, J.C., 1981. Early Paleozoic glaciation and Gondwana drift, in McElhinny. M.W.., and Valencio. D.A., eds., Paleoreconstructions of the continents: American Geophysical Union and Geological Society of America. Geodynamics Series, v. 2, p. 45-49.

Destombes, J.. Hollard, H., and Willefert, S. 1985. Lower Paleozoic of Morocco, in Holland, C.H., ed., Lower Palueozoic of north-western and west-central Africa, v. 4 of Lower Palaeozoic rocks of the world: Chichester. England, John Wiley, p. 91-336.

Deynoux, M. 1980. Les formations glaciaires du Précambrien terminal et de la tin de l'Ordovicien en Afrique de l'Ouest; deux exemples de glaciation d'inlandsis sur une plate-forme stable: Marseille. France, Travaux des Laboratoires des Sciences de lat Terre, St. Jérôme. publication of D.Sc. thesis of 1978, ser. B. no. 17, 554 p.

1985, Terrestrial or waterlain glacial diamictites? Three case studies from the Late Precambrian and Late Ordovician glacial drifts in West Africa: Palaeogeography, Palaeoclimatology, Palaececology, v. 51, p. $97-141$
Deynoux, M., Sougy, J., and Trompette. R., 1985, Lower Paleozoic of west Africa and the western part of central Africa, in Holland, C.H., ed. Lower Palaeozoic of north-western and west-central Africa, v. 4 of Lower Palaeozoic rocks of the world: Chichester, England, John Wiley, p. $337-495$.

Dionne. J.C., 1985, Formes, figures, et faciès sédimentaires glacials des estrans vaseux des régions froides: Palaeogeography, Palacoclimatology. Palaeoecology, v. 51, p. 415-451

Ekren. B.E., Vaslet, D., Berthiaux, A., Le Strat. P., and Fourniguet, J., 1987. Geologic map of the Ha'il quadrangle, sheet 27E, Kingdom of Saudi Arabia: Saudi Arabian Deputy Ministry for Mineral Resources Geoscience Map GM-115 A, scale 1:250,000.

El-Khayal, A.A., 1985, Some Silurian (Llandovery) monograptids from Saudi Arabia: Scripta Geologica, v. 80, p. 15-22.

1987, Silurian graptolites from the Qusayba Shale (Llandovery) of central Saudi Arabia: Geological Society of Denmark, Bulletin, v. 35 , p. $125-133$.

Fontaine, J-M., 1981. La plate-forme arabe et sa marge passive au Mésozoïque, l'exemple d'Hazro (SE Turquie): Orsay, France, University of Paris Sud, Ph.D. thesis, 270 p.

Helal, A.H., 1964, On the occurrence of lower Palenzoic rocks in Tabuk area. Saudi Arabia: Neues Jahrbuch für Geologie und Paläontologie Monatshefte, v. 7, p. 391-415.

1965. Stratigraphy of outcropping Palcozoic rocks around the northern edge of the Arabian Shield (within Saudi Arabia): Zeitschrift der Deutschen Geologischen Gesellschaft, v. 117, p. 506-543

Issawi, B., and Jux, U., 1982, Contributions to the stratigraphy of the Paleozoic rocks in Egypt: Geological Survey of Egypt Paper 64. 28 p.

Kellog, K.S., Fourniguet, J., Janjou, D., and Minoux, L., 1986, Geologic map of the Wadi Tathlith quadrangle, sheet 20G, Kingdom of Saudi Arabia: Saudi Arabian Deputy Ministry for Mineral Resources Geoscience Map GM-103 A, scale 1:250,000.

Klitzsch, E., 1981, Lower Palaeozoic rocks of Libya, Egypt, and Sudan, in Holland, C.H. . ed., Lower Palaeozoic of the Middle East, eastern and southern Africa. and Antarctica, v. 3 of Lower Palaeozoic rocks of the world: Chichester, England, John Wiley, p. 131--163.

Legrand, P., 1985, Réflexions sur la transgression silurienne au Sahara algérien: Congrès National des Sociétés Savantes, 110 ème. Montpellier, France. 1985, Scction Sciences, Actes, v. VI, p. 223-244.

Le Métour. J., 1988, Géologie de l'Autochtone des Noutagues d'Oman: la fenetre du Saih Hatat: Orlêans, France. Documents du Bureau de Recherches Géologiques el Minières, no. 129, $430 \mathrm{p}$.

Lovelock. P.E.R., Potter, T.L., Walsworth-Bell, E.B., and Wiemer, W.M., 1981. Ordovician rocks in the Oman Mountains; the Amdeh Formation: Geologie en Mijnbouw, v. 60. p. 487-495.

Maarleveld, G.C., 1965. Frost mounds, a summary of the literature of the past decade: Haarlem, The Netherlands, Mededelingen van de Geologische Stichting, Nieuwe Serie no. 17, p. 7-20.

Manivit. J., Vaslet, D., Berthiaux. A., Le Strat, P., and Fourniguet. J.. 1986. Geologic map of the Buraydah quadrangle, sheet 26G, Kingdom of Saudi Arabia: Saudi Arabian Deputy Ministry for Mineral Resources Geoscience Map GM-114 A, scale 1:250,000.

McClure, H.A., 1978, Early Paleozoic glaciation in Arabia: Palaeogeography, Palacoclimatology, Palaeoecology, v. 25, p. 315-326.

1980. Permian-Carboniferous glaciation in the Arabian Peninsula: Geological Society of America Bulletin, v. 91, part 1. p. 707-712.

1988, The Ordovician-Silurian boundary in Saudi Arabia: Bulletin of the British Museum (Natural History, Geology Series), v. 43. p. $155-163$.

Powers, R.W., 1968, Lexique stratigraphique international, Asie, v. III, fascicule 10b1, Saudi Arabia: Paris, Centre National de la Recherche Scientifique, $177 \mathrm{p}$.

Powers, R.W., Ramirez, L.F., Redmond, C.D., and Elberg, E.L., Jr., 1966, Geology of the Arabian Peninsula: Sedimentary geology of Saudi Arabia: U.S. Geological Survey Professional Paper 560-D, 147 p.

Rognon, P., Biju-Duval, B., and Charpal, O. de, 1972. Modèles glaciaires dans l'Ordovicien supérieur saharien, phases d'érosion et glaciotectonique sur la bordure nord des Eglab: Revue de Géographie Physique et de Géologie Dynamique, v, XIV, p. 507-528.

Rust, I.C. 1981. Lower Palaeozoic rocks of southern Africa, in Holland, C.H.. ed., Lower Palaeozoic rocks of the Middle East, eastern and 
southern Africa, and Antarctica, v. 3 of Lower Palaeozoic rocks of the world: Chichester, England, John Wiley, p. 165-187.

Saxena, G.N., and Assefa, G., 1983, New evidence on the age of the glacial rocks of northern Ethiopia: Geological Magazine, v. 6, p. 549-554.

Scotese, C.R., Bambach, R.K., Barton, C., Van Den Voo, R., and Ziegler, A.M., 1979, Paleozoic base maps: Journal of Geology, v. 87, p. 217277.

Smith, A.G., Hurley, A.M., and Briden, J.C., 1981, Phanerozoic paleocontinental world maps: Cambridge, England, Cambridge University Press, $102 \mathrm{p}$.

Spjeldnaes, N., 1981, Lower Palaeozoic palaeoclimatology, in Holland, C.H., ed., Lower Palaeozoic of the Middle East, eastern and southern Africa, and Antarctica, v, 3 of Lower Palaeozoic rocks of the world: Chichester, England, John Wiley, p. 199-256.

Steineke, M., Bramkamp, R.A., and Sander, N.J., 1958, Stratigraphic relations of Arabian Jurassic oil, in Weeks, L.G., ed., Habitat of OilA Symposium, Tulsa, Oklahoma, USA, 1958: American Association of Petroleum Geologists, p. 1294-1329.

Stöcklin, J., 1972, Lexique stratigraphique international, Asie, v. III, fascicule 9bl, Iran central, septentrional et oriental: Paris, Centre National de la Recherche Scientifique, p. 5-283.

Thralls, W.H., and Hasson, R.C., 1956, Geology and oil resources of eastern Saudi Arabia: International Geological Congress, 20th, Mexico City, 1956, Symposium sobre yacimientos de petroleo y gas, v. 2 . p. 9-32.

Vaslet, D., 1987a, Early Paleozoic glacial deposits in Saudi Arabia, a lithostratigraphic revision: Saudi Arabian Directorate General for Mineral Resources Technical Record BRGM-TR-07-1, 24 p.

1987b, The Paleozoic (pre-Late Permian) of central Arabia and correlations with neighboring regions: Saudi Arabian Directorate General for Mineral Resources Technical Record BRGM-TR-07-2, 167 p. -1987c, Géologic du Paléozoïque Permien Supérieur, Trias,

Jurassique; lithostratigraphie, in Le Nindre, Y.-M., Manivit, J., and Vaslet, D., Histoire géologique de la bordure occidentale de la plate-forme arabe du Paléozoïque inférieur au Jurassique supérieur: Paris, University of Paris VI, D.Sc. thesis, v. 1, 413 p.

1989, Late Ordovician glacial deposits in Saudi Arabia: A lithostratigraphic revision of the early Paleozoic succession: Saudi Arabian Deputy Ministry for Mineral Resources Professional Paper 3 , p. 13-44.
Vaslet, D., Berthiaux, A., Le Strat, P., Kellogg, K.S., and Vincent, P.L., 1987, Geologic map of the Baq'a quadrangle, sheet $27 \mathrm{~F}$, Kingdom of Saudi Arabia: Saudi Arabian Deputy Ministry for Mineral Resources Geoscience Map GM-116 A, scale 1:250,000.

Vaslet, D., Beurrier, M., Villey, M., Manivit, J., Le Strat, P., Le Nindre, Y.-M., Brosse, J.M., Berthiaux, A., and Fourniguet, J., 1985, Geologic map of the Al Faydah quadrangle, sheet 25G, Kingdom of Saudi Arabia: Saudi Arabian Deputy Ministry for Mineral Resources Geoscience Map GM-102 A, scale 1:250,000.

Williams, P.L., Vaslet, D., Johnson, P.R., Berthiaux, A., Le Strat, P., and Fourniguet, J., 1986, Geologic map of the Jabal Habashi quadrangle, sheet 26F. Kingdom of Saudi Arabia: Saudi Arabian Deputy Ministry for Mineral Resources Geoscience Map-GM-98 A, scale 1:250,000.

Wolfart, R., 1981, Lower Palaeozoic rocks of the Middle East, in Holland, C.H., ed., Lower Palaeozoic of the Middle East, eastern and southern Africa, and Antarctica, v. 3 of Lower Palaeozoic rocks of the world: Chichester, England, John Wiley, p. 5-30.

Wolfart, R., Bender, F., and Stein, V., 1968, Stratigraphie und fauna des Ober-Ordoviziums (Caradoc-Ashgill) und Unter-Silurs (Unter-Llandovery) von Sudjordanien: Geologisches Jarhbuch, v. 85, p. 517-564.

Young, G.M., 1981, Early Palaeozoic tillites of the northern Arabian Peninsula, in Hambrey, M.J., and Harland, W.B., eds., Earth's pre-Pleistocene glacial record: Cambridge, England, Cambridge University Press, p. 338-340.

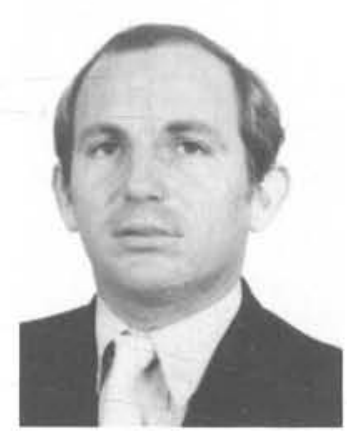

Dr. Denis Vaslet (Bureau de Recherches Géologiques et Minières, BP 6009, Orléans-la-Source, France) is responsible for the cover rocks mapping project of the Saudi Arabian Directorate General of Mineral Resources. During the last 10 years, he has been involved in revising the Phanerozoic stratigraphy of Saudi Arabia. He has specialized in the lower Paleozoic rocks, and complete lithostratigraphic revision of these has been carried out as a result of his work. 